\title{
Scientific production on housing for autonomous elderly persons: an integrative literature review
}

Roberta de Miranda Henriques Freirel, ${ }^{12}$

Nivaldo Carneiro Junior ${ }^{2}$

\section{Abstract}

Objective: To analyze Brazilian scientific production on housing for autonomous elderly persons. Method: A descriptive, analytical integrative review type study was carried out. The following guiding question was defined: what is the Brazilian scientific production relating to housing for autonomous elderly persons in indexed on-line periodicals from 2000 to 2015? Results: Thirty-three articles were identified in total, of which only 13 met the inclusion criterion. Using the Content Analysis technique, the following categories were formed: Modalities of housing for the elderly; Public housing policies for the elderly and Housing and quality of life. Conclusion: Most of the studies discussed types of housing for the elderly, falling into the category "Modalities of housing for the elderly", and identifying a tendency towards one-person dwellings. In relation to the category "Public housing policies for the elderly", the articles reflected on the rights and the guarantees of the elderly in relation to a suitable home. The "Housing and quality of life" category aimed to compare the quality of life of elderly people living alone or with a partner, as well as their perception of exclusive condominium developments for this population. There is a need for research on the issue in question, since there is an increase in the number of elderly people without housing, making it necessary for the state to meet this demand.
Keywords: Housing for the Elderly. Elderly. Public Policies.

\footnotetext{
Universidade Federal de Campina Grande, Unidade Acadêmica de Enfermagem. Cajazeiras, Paraíba, Brasil.

2 Faculdade de Ciências Médicas da Santa Casa de São Paulo, Departamento de Saúde Coletiva. São Paulo, SP, Brasil.
} 


\section{INTRODUCTION}

The accelerated growth of the elderly population is a current and established occurrence in today's global reality. It represents an important transformation in the way society is organized ${ }^{1}$, and has numerous economic and social consequences for the population as a whole and especially for the elderly.

Aging is a serious concern in Brazil due to its repercussions for overall society in a context of marked social inequality, poverty and the fragility of social institutions, especially as the country undergoes a reassessment of its public policies and includes the elderly as a focus of attention ${ }^{2}$.

The aging process therefore places demands on the State and society. Among these are the provision of housing that is suitable for the needs of the elderly population ${ }^{3}$.

Brazil has developed legislation, policies and programs to improve the living conditions of the elderly, seeking to ensure the integrity and dignity of this population ${ }^{3}$ and extending the effective protection of their rights, including to a suitable home, whether within their family unit or unaccompanied by relatives, when they so choose, or even in longterm public or private institutions ${ }^{3-6}$.

The State is responsible for creating public policies that minimize the housing needs of the low-income elderly population, carrying out specific projects and programs and allocating a minimum of $3 \%$ of residential housing units in public housing programs for priority acquisition by the elderly ${ }^{4,6}$.

In this context, and in order to stimulate reflection and contribute to the debate on how and where these elderly people should live and the consequences that this has for society, the objective of the present study was to analyze Brazilian scientific production in the field of aging on the issue of housing for the elderly.

\section{METHOD}

A descriptive, analytical integrative review type study ${ }^{7}$ was carried out, with the objective of synthesizing the results (secondary analysis) of previous studies (primary analysis). As a general rule, this method is composed of the following steps: elaboration of a guiding question; searching or sampling of the literature; data collection; critical analysis of included studies; discussion of the results and presentation of the review. The following guiding question was defined: what is the Brazilian scientific production on housing for autonomous elderly persons in online indexed periodicals between 2000 and 2015?

An online search was conducted between April and May 2016 for indexed Brazilian journals available for public access through the databases of the Latin-American and Caribbean System on Health Sciences Information (LILACS) and the Scientific Electronic Library Online (SciELO), as well as that of the Medical Literature Analysis and Retrieval System Online (Medline), by searching the Capes portal with the descriptor "aging"; "old age"; "elderly" together with one or more of the following descriptors: "housing"; "habitation"; "housing for the elderly"; "habitation for the elderly".

For inclusion in the study, articles were required to meet the following criteria: be in Portuguese; be available in the databases selected for the proposed study; be available in full and published in the period from 2000 to 2015 in the form of a scientific article, and not discuss Long Term Care Facilities for the Elderly (LTCF).

Data analysis was performed through an exploratory, selective and analytical reading, aimed at identifying the subject of the study and its relationship to the issue of housing for autonomous elderly persons. Using the Content Analysis technique ${ }^{8}$, it was possible to classify the studies into the following categories: Type of housing for the elderly; Public housing policies for the elderly and Housing and quality of life. The Content Analysis technique uses inductive reasoning whereby themes and categories emerge from the data through judicious examination and constant comparisons?

\section{RESULTS AND DISCUSSION}

A total of 33 productions were identified. Of these, only 13 articles met the inclusion criterion, as shown in figure 1 . 


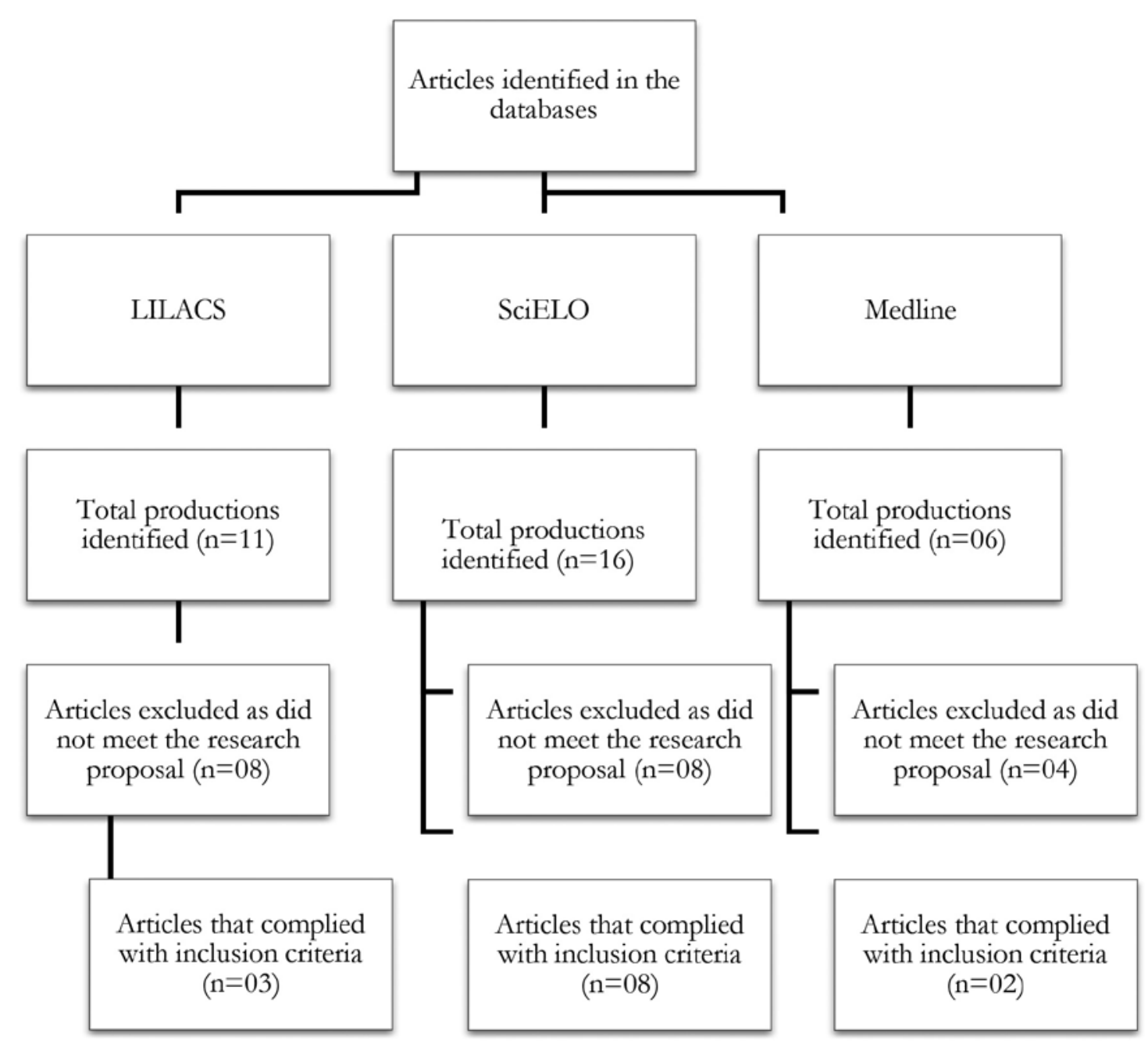

Figure 1. Articles identified in the databases. São Paulo, 2016.

The number of articles on housing for autonomous elderly persons found in Brazilian scientific production showed that, although the theme is highly relevant in a country where the elderly population is growing in an accelerated manner, it remains little explored in the field of human aging.

Regarding the periodicals in which the articles were published, $38.4 \%$ of the production was concentrated in thematic publication in the area of Gerontology in 2010, the subject of which was "Housing in Old Age".
Considering the significant increase in the Brazilian elderly population, the country faces several challenges, one of which is the question of how and where these elderly persons will live and the consequences that this entails for society. Seven studies were published by Brazilian authors focusing on category 1 (Types of housing for the Elderly), which deal with some housing modalities such as single-person dwellings, shared housing, hostels and condominiums for the elderly, as shown in Chart 1. 
Chart 1. Articles included in integrative review, including title, author(s), year and aim of study in the category Types of Housing for Elderly Persons. São Paulo, 2016.

\begin{tabular}{|c|c|c|c|}
\hline \multicolumn{4}{|c|}{ Types of Housing for Elderly Persons } \\
\hline Title & Authors & Year & Study objective \\
\hline $\begin{array}{l}\text { The art of living alone and } \\
\text { being happy in old age }{ }^{9}\end{array}$ & $\begin{array}{l}\text { Santos DF, } \\
\text { Tomazzoni AMR, } \\
\text { Lodovici FMM, } \\
\text { Medeiros SAR }\end{array}$ & 2010 & $\begin{array}{l}\text { To analyze the reasons that leads a person to live alone } \\
\text { when elderly and what they think about LTCFs - } \\
\text { Long Term Care Facilities. }\end{array}$ \\
\hline $\begin{array}{l}\text { The constitution of } \\
\text { single-person households } \\
\text { in a condominium for the } \\
\text { elderly }{ }^{10}\end{array}$ & $\begin{array}{l}\text { Teston EF, Marcon } \\
\text { SS }\end{array}$ & 2014 & $\begin{array}{l}\text { Identify the perception of elderly persons living alone } \\
\text { about the constitution of single-person households. }\end{array}$ \\
\hline $\begin{array}{l}\text { The relation between } \\
\text { income and living alone } \\
\text { for São Paulo elderly } \\
\text { persons, } 2000^{11}\end{array}$ & $\begin{array}{l}\text { Camargos MCS, } \\
\text { Machado CJ, } \\
\text { Rodrigues RN }\end{array}$ & 2007 & $\begin{array}{l}\text { To analyze the relationship between income and living } \\
\text { alone for elderly São Paulo residents, in 2000, using } \\
\text { the database of Project Sabe (Health, Welfare and } \\
\text { Aging in Latin America and the Caribbean). }\end{array}$ \\
\hline $\begin{array}{l}\text { The elderly, family and } \\
\text { the household: a narrative } \\
\text { review about the decision } \\
\text { to live alone }\end{array}$ & $\begin{array}{l}\text { Camargos MCS, } \\
\text { Rodrigues RN, } \\
\text { Machado CJ }\end{array}$ & 2011 & $\begin{array}{l}\text { Establish a basis of argumentation to better } \\
\text { understand the reasons that lead an elderly person to } \\
\text { live alone and how transfers are processed (flows of } \\
\text { resources, actions and information that are exchanged } \\
\text { and circulated) when living alone. }\end{array}$ \\
\hline $\begin{array}{l}\text { New Forms of Living: } \\
\text { Shared Housing for the } \\
\text { Elderly }^{13}\end{array}$ & Fortes R & 2010 & $\begin{array}{l}\text { Show how the lives of elderly persons living in a } \\
\text { shared house can be pleasurable and beneficial. }\end{array}$ \\
\hline $\begin{array}{l}\text { Sensations of living and } \\
\text { housing for elderly people } \\
\text { from a hostel }{ }^{14}\end{array}$ & $\begin{array}{l}\text { Silva ACL, } \\
\text { Mincache GB, } \\
\text { Souza Rosa MA, } \\
\text { Mutchnik VI }\end{array}$ & 2010 & $\begin{array}{l}\text { Contribute socially through the elaboration of } \\
\text { proposals that understand subjective feeling in homes } \\
\text { aimed at the elderly and what aspects make such } \\
\text { individuals feel at home. }\end{array}$ \\
\hline $\begin{array}{l}\text { A model for housing for } \\
\text { the elderly: the case of Vila } \\
\text { dos Idosos do Pari-São } \\
\text { Paulo }(S P)^{15}\end{array}$ & De Deus SIA & 2010 & $\begin{array}{l}\text { Analyze the Pari Vila dos Idosos Armando Amadeu } \\
\text { Housing Scheme, known as Vila dos Idosos (Town for } \\
\text { Older Persons). }\end{array}$ \\
\hline
\end{tabular}

The creation of single-person households seems to be an increasingly present trend in Brazilian life due to a reduction in the number of children, an increase in the number of divorces, changes in lifestyle, improved health conditions and increased longevity. The trend is inevitable even for those who, despite feeling lonely or abandoned, do not have other people with whom they can reside ${ }^{15}$. In addition, while living alone may be indicative of successful aging and such elderly people are likely to retain their independence and autonomy, equally they may be more frail and susceptible to the risks of becoming ill, due to a lack of capacity for self-care and physical safety ${ }^{16}$.
This statement corroborates some excerpts from the studies described below:

" [...] the relationship between the elderly and their home represents the expression of their identity, with their significant and personal brand, for the construction of their means of protection and wellbeing, a space under their power and control"'.

"[...] improvements in financial conditions may allow a large proportion of the elderly to live alone, exercising their choice for independence and, at the same time, maintaining contact with the family and support networks" ${ }^{\prime 11}$. 
"[...] the single-person domicile emerges from separation or the death of a companion. Others see it as a choice and opportunity to start over" ${ }^{10}$.

"[...] In view of the recent trend of a reduction in the number of children, an increase in divorces, changes in lifestyle, individualism, an improvement in the health conditions of the elderly and a consequent increase in longevity, especially for women, it is expected that there will be a growth in single-person households, or in other words the number of elderly people living alone, in coming years" ${ }^{12}$.

The health complications that may affect elderly people living only were also noted, as the following extracts show:

"[...] It is precisely at this moment that the feeling of sadness affects the heart, sometimes leading to depression. Some have mentioned the fear of suffering an accident and not having anyone to turn to. These elderly people are not comfortable asking strangers for help and do not enjoy the obligation of telling their children every time they visit the doctor. However, they feel fine during the day when occupied by their daily activities"?.

"[...] Possible imbalances in the general health situation, such as sequelae, whether temporary or permanent, which may limit the performance of activities of daily living, were the main disadvantages pointed out regarding the singleperson domicile"10.

In category 2 (Public housing policies for the elderly), four studies were identified that discuss the adequacy of public policies and actions that can reduce the housing needs generated by the increase of the elderly population in Brazil, as shown in Chart 2 below.

Chart 2. Articles included in integrative review, including title, author(s), year and aim of study in the category Public policies on housing for the elderly. São Paulo, 2016.

\begin{tabular}{|c|c|c|c|}
\hline \multicolumn{4}{|c|}{ Public policies on housing for the elderly } \\
\hline Title & Authors & Year & Study objective \\
\hline $\begin{array}{l}\text { Housing for the elderly: a } \\
\text { policy yet to be guaranteed }{ }^{16}\end{array}$ & $\begin{array}{l}\text { Almeida Prado AR, } \\
\text { Besse M, Dutra LN }\end{array}$ & 2010 & $\begin{array}{l}\text { How to guarantee housing with quality of life for } \\
\text { an aging population. }\end{array}$ \\
\hline $\begin{array}{l}\text { The environment of aging } \\
\text { in Brazil: why plan? }\end{array}$ & Mendes FRC, Côrte B & 2009 & $\begin{array}{l}\text { The article reflects on the home environment and } \\
\text { the complexity involved in aging. It discusses public } \\
\text { and housing policies that contemplate accessible } \\
\text { and adaptable residential projects, considering the } \\
\text { physiological and functional changes of aging, } \\
\text { providing environments that allow a harmonious } \\
\text { relationship in all phases of life, contributing to the } \\
\text { well-being and permanence of the elderly in their } \\
\text { home, their affective space. }\end{array}$ \\
\hline The elderly and housing ${ }^{18}$ & Schussel ZGL & 2012 & $\begin{array}{l}\text { To discuss the urban policies that are being } \\
\text { implemented in Brazil, in particular, social housing } \\
\text { policies and their capacity to } \\
\text { respond to changes in the age profile. }\end{array}$ \\
\hline $\begin{array}{l}\text { Public housing policies for } \\
\text { the elderly: the vila dignidade } \\
\text { (dignity town) of the state } \\
\text { of São Paulo }\end{array}$ & Monteiro JC & 2012 & $\begin{array}{l}\text { Analyze exclusive condominiums for elderly } \\
\text { persons in Itapeva and Avaré, both in the state of } \\
\text { São Paulo, known as Vila Dignidade, part of a new } \\
\text { housing policy for the elderly in the state. }\end{array}$ \\
\hline
\end{tabular}


In this sense, in addition to the 1988 Constitution $^{20}$, which guarantees the elderly, whether through their family, society or the State, the right to decent housing, the National Policy for the Elderly ${ }^{21}$ and Ordinance $73^{22}$ of the former Ministry of Social Security and Assistance discuss several aspects related to housing for the elderly, such as ways of improving habitability conditions and the adaptation of housing, models for financing housing projects, forms of living considering their physical and mental state, respecting socioeconomic indicators, the profile of the elderly and the sociocultural characteristics of each locality.

However, the main legal document related to the elderly population is Law 10,741, dated October 1, 2003, which establishes the Statute of the Elderly ${ }^{23}$, an instrument that regulates the rights guaranteed to persons aged sixty or over. The Statute is a central reference document that ensures that public policies deal properly with the process of population aging.

Articles 37 and 38 are worthy of note, and discuss "the right to decent housing with their family of
origin, or alone, should they wish, in a public or
private entity, as well as the reservation of at least
$3 \%$ of residential units in housing programs to
meet housing demand in the elderly population" 23

The UM, meanwhile, established the International Plan of Action on Aging in 2002 24 . Theme 1 of this plan (Housing and living conditions), exposes the major concern of society with the issues of housing and accessibility for the elderly population and sets out in priority orientation III the creation of a favorable and suitable environment.

From the same perspective, article 24 of the Inter-American Convention on Protecting the Human Rights of Older Persons ${ }^{25}$, deals with the right to adequate and decent housing and to live in safe, healthy, accessible and adaptable environments adapted to their preferences and needs. The same article states that

"State bodies should guarantee the right of the elderly to decent and adequate housing and adopt policies to promote the right to housing and access to land by recognizing the needs of the elderly and giving priority to those who are vulnerable".
In light of the above, some excerpts from the studies that relate to category 2 , which deals with the importance of Public Policies in the field of housing for the elderly population, should be highlighted:

“[... In this sense, public housing policies are necessary, since in general the elderly population does not have the financial resources to buy or rent a house in the real estate market"16.

"[...] the housing policies for this age group require flexible programs that adapt to different situations. These considerations are also true for the other age groups, whose cultural and economic diversity requires the attention of the federal government, through social programs which do not replicate generic solutions and solve problems with local characteristics""18.

“[...] The major challenge is to make municipal governments implement housing policies for aging people and ensure the approval of projects and works and the application of legislation that proposes buildings with universal accessibility"18.

"[...] the State is responsible for public policies aimed at mitigating social problems, especially those related to housing, aimed at the realization of the precepts of a democratic society of rights" ${ }^{19}$.

According to the Coordination of Population and Social Indicators of the $\mathrm{IBGE}^{26}$, in its Basic Municipal Information survey 2011, while most municipalities have programs aimed at the elderly in several areas, there is no reference document on housing for the elderly. Although there is a housing deficit of approximately 5.5 million housing units in Brazil, there is insufficient information relating to the size of this deficit for people over 65 .

Some Brazilian states offer housing programs for the elderly ${ }^{19}$, however, such as the state of São Paulo, whose housing policy includes programs such as Vila Dignidade de Avaré, Itapeva, Recanto Feliz and Vila dos Idosos, and the state of Paraíba, with its Cidade Madura (Mature City) program. In addition to providing the right to decent housing for the elderly, these housing policies value the maintenance of quality of life, and represent an important parameter for the evaluation of public policies.

Based on the survey of the studies produced on housing for the elderly, two papers were found 
that related to Category 3 (housing and quality of life of the elderly), focusing on quality of life and discussing, in general terms, the importance of developing scientific studies that deal with the quality of life of the elderly and types of housing, as shown in Table 3 below.

Chart 3. Articles included in integrative review, including title, author(s), year and aim of study in the category Housing and quality of life of the elderly. São Paulo, 2016.

\begin{tabular}{|l|l|l|l|}
\hline \multicolumn{4}{|l|}{ Housing and quality of life of the elderly } \\
\hline Title & Authors & Year & Study objective \\
\hline $\begin{array}{l}\text { Quality of life of residents of } \\
\text { an exclusive condominium for } \\
\text { the elderly }{ }^{27}\end{array}$ & $\begin{array}{l}\text { Teston LJ, Ferraz } \\
\text { EM, Silva S }\end{array}$ & 2014 & $\begin{array}{l}\text { Compare the quality of life of elderly persons who } \\
\text { live alone with those who live with a partner. }\end{array}$ \\
\hline $\begin{array}{l}\text { Quality and conditions of } \\
\text { live from the perspective of } \\
\text { residents of a condominium } \\
\text { for the elderly }\end{array}$ & $\begin{array}{l}\text { Teston LJ, Marcon } \\
\text { SS }\end{array}$ & 2014 & $\begin{array}{l}\text { Identify how residents of a "condominium for the } \\
\text { elderly" perceive the quality and conditions of live } \\
\text { in this type of housing. }\end{array}$ \\
\hline
\end{tabular}

The studies emphasize that the concept of quality of life is still hard to grasp, since it involves the perception of the individuals about their position in life and individual factors as well as cultural, social and environmental contexts ${ }^{27}$.

While quality of life may vary from one individual to another depending on their goals and the scale of their life expectancies, however, it is common and universal in some respects, such as physical and psychological well-being, social relations, environment, level of independence and personal beliefs or religiosity ${ }^{29,30}$ as shown by the following excerpts from the publications included in category 3 .

“[...] when defining QOL, the elderly value aspects related to health, but also demonstrate that this is not understood simply as the absence of disease"27.

“[...] Quality of Life is more than having good mental or physical health, it is feeling good about oneself, about life, about one's loved ones, and finally, about balance. These are often complicated situations for this population that suffers from sedentary lifestyles and dependence in daily activities" 28

It should be pointed out that the studies presented here describe the quality of life of a specific population, namely the elderly, and how this relates to their housing.
"[...] the quality of life of the elderly can vary depending on their housing arrangement, their living environment, time and the priorities of life"27.

Based on the studies that tackle this issue, it is clear that quality of life in old age depends on lifelong interactions and many elements, such as longevity, biological health, mental health, satisfaction, cognitive control, social competence, productivity, activity, efficacy cognitive, social status, income, the continuity of family and occupational roles, and continuity of informal relationships with friends ${ }^{31}$.

\section{CONCLUSION}

The present study found Brazilian scientific production available in full on the issue of housing for the autonomous elderly to be incipient and little explored, with most of the studies on the subject related to types of housing for the elderly.

Elderly persons in Brazil today have to face not only the physical and health demands arising from the aging process itself, but also the social and economic crisis that the country is experiencing. This reinforces the need to broaden the understanding of the implications that population aging brings to society and thus to the issue of housing. 
It can be seen that public policies in the area of aging highlight the family as the main source of housing support, followed by Long-term Care Facilities (LTCF). Although there are some changes in terms of national public housing programs for autonomous elderly people, these are still very restricted in what they offer, suggesting that many of these policies need to become more effective and consider the reality of Brazil.

The present study has some limitations, such as that it analyzed only scientific production relating to the autonomous elderly and did not consider studies on LTCF, as the elderly living in such institutions may present some degree of dependence. Despite this, it is believed that it contributes to the compilation of data on the issue of housing for the elderly.

It is hoped, furthermore, to raise the interest of researchers in the field of aging, and to include this highly relevant theme in Brazilian research projects, as the number of elderly people without housing increases every year, and action from the State is required to meet such housing demands.

\section{REFERENCES}

1. Organização Mundial de Saúde. O caminho para a cobertura universal. Relatório Mundial da Saúde. Geneva: WHO; 2005.

2. Areosa SVC, Araújo CK, Cardoso CMC, Moreira EP. Envelhecimento: relações pessoais e familiares. Barbarói. 2012;36(Ed. Esp.):120-32.

3. Fernandes MTO, Soares SM. O desenvolvimento de políticas públicas de atenção ao idoso no Brasil. Rev Esc Enferm USP. 2012;46(6):1494-1502.

4. Da Costa FM, Nakata PT, De Morais EP. Estratégias desenvolvidas pelos idosos residentes na comunidade para morarem sozinhos. Texto \& Contexto Enferm. 2015;24(3):818-25.

5. Nogueira MF. Avaliação multidimensional da qualidade de vida em idosos: um estudo no Curimataú ocidental paraibano [Tese]. Natal: Universidade Federal do Rio Grande do Norte; 2016.

6. Brasil. Lei no ${ }^{\circ}$ 10.741, de $1^{\circ}$ de outubro de 2003. Dispõe sobre o Estatuto do Idoso e dá outras providências. Diário Oficial da União. 03 out. 2003: 11. Disponível em: http://www.planalto.gov.br/ ccivil_03/leis/2003/L10.741.htm.

7. Baldini SC, Hoga LAK, Peduzzi M, Sangaleti C, Yonekura T, Audebert Silva DRAD. Revisão integrativa: conceitos e métodos utilizados na enfermagem. Rev Esc Enferm USP. 2014;48(2):335-45.

8. Bardin L. Análise de Conteúdo. Lisboa: Edições 70; 2009.

9. Santos DF, Tomazzoni AMR, Lodovici FMM, Medeiros SAR. A arte de morar só e ser feliz na velhice. Rev Kairós. 2010;13:109-23.

10. Teston EF, Marcon SS. A constituição de domicílios unipessoais em condomínio específico para idosos. Rev Enferm UERJ. 2014;22(5):610-14.

11. Camargos MCS, Machado CJ, Rodrigues RN. A relação entre renda e morar sozinho para idosos paulistanos: 2000. Rev Bras Estud Popul. 2007;24(1):37-51.

12. Camargos MCS, Rodrigues RN, Machado CJ. Idoso, família e domicílio: uma revisão narrativa sobre a decisão de morar sozinho. Rev Bras Estud Popul. 2011;28(1):217-30.

13. Fortes R. Novas formas de morar: repúblicas para idosos. Rev Kairós. 2010;13:157-67.

14. Silva ACL, Mincache GB, Souza Rosa MA, Mutchnik VI. Sensações do morar e a concretização de moradia para idosos egressos de um albergue. Rev Kairós. 2010;13:169-93.

15. De Deus SIA. Um modelo de moradia para idosos: o caso da Vila dos Idosos do Pari-São Paulo (SP). Rev Kairós. 2010;13:195-213.

16. Almeida Prado AR, Besse M, Dutra LN. Moradia para o idoso: uma política ainda não garantida. Rev Kairós. 2010;13:5-17.

17. Mendes FRC, Côrte B. O ambiente da velhice no país: por que planejar? Rev Kairós. 2009;12(1):197-212.

18. Schussel ZGL. Os idosos e a habitação. Rev Kairós. 2012;15(4):53-66.

19. Monteiro LCA. Políticas públicas habitacionais para idosos: um estudo sobre os condomínios exclusivos [Tese]. São Carlos: Universidade Federal de São Carlos; 2012.

20. Brasil. Congresso Nacional. Constituição República Federativa do Brasil 1988. Diário Oficial da União. 05 out. 1988;191-A:1.

21. Brasil. Lei no. 8.842, de 04 de janeiro de 1994. Dispõe sobre a Política Nacional do Idoso, cria o Conselho Nacional do Idoso e dá outras providências. Diário Oficial da União. 05 jan. 1994:1. 
22. Brasil. Portaria n 73 de 10 de maio de 2001. Estabelece normas de funcionamento de serviços de atenção ao idoso no Brasil, nas modalidades previstas na Política Nacional do Idoso, e aos desafios que o crescimento demográfico impões ao país. Diário Oficial da União. 14 maio 2001. Seção 1:174.

23. Brasil. Lei n. 10.741, de $1^{\circ}$ de outubro de 2003. Dispõe sobre o Estatuto do Idoso e dá outras providências. Câmara dos Deputados. (2001?) Disponível em: http://www2.camara.leg.br/legin/marg/portar/2001/ portaria-73-10-maio-2001-325960-publicacaooriginal1-seas.html

24. Organização das Nações Unidas. Plano internacional. Plano de Ação Internacional de Madrid sobre Envelhecimento: Relatório da II Assembleia Mundial sobre o Envelhecimento. Madrid: ONU; 2002.

25. Organização dos Estados Americanos. Convenção Interamericana sobre a proteção dos direitos humanos dos idosos. [sem local]: ONU; 2015.

26. Instituto Brasileiro de Geografia e Estatística. Pesquisa de Informações Básicas Municipais. Rio de Janeiro: IBGE; 2011.
27. Teston LJ, Ferraz EM, Silva S. Qualidade de vida de residentes em condomínio exclusivo para idosos. Saúde (Santa Maria). 2014;35(1):73-80.

28. Teston LJ, Marcon SS. Qualidade e condições de vida sob a ótica dos residentes de um condomínio do idoso. Rev Gaúch Enferm. 2014;35(1): 124-30.

29. Jürschik P, Botigué T, Nuin C, Lavedán A. Estado de ánimo caracterizado por soledad y tristeza: factores relacionados em personas mayores. Gerokomos. 2013;24(1):14-7.

30. Fang Ml, Woolrych R, Sixsmith J, Canham S, Battersby L, Sixsmith A. Place-making with older persons: establishing sense-of-place through participatory community mapping workshops. Soc Sci Med. 2016;168: 223-29.

31. Woolrych R, Gibson N, Sixsmith J, Sixsmith A. "No Home, No Place": Addressing the Complexity of Homelessness in Old Age Through Community Dialogue. J Housing Elder. 2015;29(3):233-58.

32. Ferraz TE, Marcon SS. "Comparative study of quality of life of elderly living in condominiums versus community dwellers." Invest Educ Enferm. 2015;33(1):53-62. 